- Long chain fatty acids were absorbed more rapidly than the short ones.

- Rate of absorption was proportional to the concentrations of VFA considered,

- Rate of absorption was more rapid with an acid $\mathrm{pH}$ (5) than with a neutral $\mathrm{pH}$ (see table $\mathrm{r}$ ).

Only the free fatty acids were absorbed on the rumen with an acid $\mathrm{pH}$ and during absorption. the $\mathrm{pH}$ of the solution was exactly increased by the value corresponding to the amount of acid absorbed.

Conversely, on the omasum, VFA were not absorbed with increasing $\mathrm{pH}$.

This phenomenon could be explained by an absorption mechanism similar to that described for rumen at $\mathrm{pH} 7$ : ion exchange (fatty acid) by bicarbonate induced by carbonic anhydrase contained in the wall. And it was shown indeed, that the wall of the omasum is particularly rich in carbonic anhydrase.

KAY showed that the absorption of VFA in the rumen plays an essential role in the maintenance of a $\mathrm{pH}$ close to neutrality. On the contrary, phenomena of acidosis could occur in the omasum, in the case of large production of VFA despite of the same rate of absorption and can probably explain certain indigestions in the omasum.

\title{
LES ÉCHANGES HYDRO-ÉLECTROLYTIQUES DU COLON TERMINAL CHEZ LE MOUTON
}

\author{
J. FARGEAS et A. DENIS \\ École nationale vétérinaire \\ 31076 Toulouse Cedex
}

Chez onze brebis à jeun depuis quarante-huit heures et anesthésiées au Pentobarbital (30 $\mathrm{mg} \mathrm{kg}^{-1} \mathrm{IV}$ ) la dialyse de la partie terminale du côlon avec une solution de Ringer contenant $0,272 \mathrm{~mol}^{-1}$ d'acétate de sodium met en évidence :

- une excrétion de potassium $\left(0,04 \mathrm{I} \pm 0\right.$, or $\mu$ Eq. $\left.\mathrm{m}^{-1} \mathrm{~cm}^{-2}\right)$ et de chlore $\left(0,02 \mathrm{I} \pm 0,06 \mu\right.$ Eq. $\left.\mathrm{m}^{-1} \mathrm{~cm}^{-2}\right)$;

- une réabsorption de sodium $\left(0,137 \pm 0,05 \mu \mathrm{Eq} . \mathrm{m}^{-1} \mathrm{~cm}^{-2}\right)$ et d'eau $(0,34 \pm 0,03$ $\left(0,34 \pm 0,03 \mu \mathrm{I} \mathrm{m}^{-1} \mathrm{~cm}^{-2}\right)$.

La pression osmotique passe de $292 \pm 3,5 \mathrm{mOsm} \mathrm{kg} \mathrm{kg}^{-1}$ à $33^{8} \mathrm{mOsm} \mathrm{kg}^{-1} \pm 4,3$ dans un délai de trois heures.

La cinétique des échanges n'est pas modifiée de façon significative par les variations de la concentration luminale en $\mathrm{Na}^{+}$. L'excrétion du $\mathrm{K}^{+}$semble relever d'un mécanisme actif particulier : elle persiste en présence d'un gradient de concentration et n'est pas affectée par le taux. de sodium.

Les résultats sont comparables avant et après perfusion d'aldostérone $\left(30 \mu \mathrm{g} \mathrm{kg}^{-1} \mathrm{~m}^{-1}\right.$ ) pendant trois heures, ou injection intramusculaire d'un inhibiteur de l'aldostérone (8 Io9 CB. I $5 \mathrm{mg} / \mathrm{kg} / \mathrm{j}$ dans les trois jours précédant l'expérience).

La même technique appliquée chez le chien confirme les données acquises dans cette espèce et retrouvées chez l'homme (réabsorption de sodium et d'eau accrue en présence d'aldostérone) et excrétion de potassium plus faible.

Il existe des différences dans la nature et le mécanisme de ces échanges ioniques entre les monogastriques et les petits ruminants. 


\author{
SUMMARY \\ THE HYDRO ELECTROLYTIC EXCHANGES \\ IN THE TERMINAL COLON OF THE SHEEP
}

In eleven ewes fasted for forty eight hours and anaesthetized with Pentobarbital (30 $\mathrm{mg}$ $\mathrm{kg}^{-1}$ I.V) the dialysis of the terminal colon with a RINGER solution containing 0.272 mol. $1^{-1}$ sodium acetate showed :

- an excretion of potassium (0.04I \pm o.or $\mu$ Eq. $\mathrm{m}^{-1} \mathrm{~cm}^{-2}$ ) and chloride (0.02I $\pm 0.06 \mu$ Eq. $\left.\mathrm{m}^{-1} \mathrm{~cm}^{-2}\right)$,

- a resorption of sodium $\left(0.137 \pm 0.05 \mu\right.$ Eq. $\left.\mathrm{m}^{-1} \mathrm{~cm}^{-2}\right)$ and water $(0.34 \pm 0.03 \mu 1$ $\left.\mathrm{m}^{-1} \mathrm{~cm}^{-2}\right)$.

The osmotic pressure raised from $292 \pm 3.5$ mOsm kg-1 to $33^{8} \pm 4.3 \mathrm{mOsm} \mathrm{kg}^{-1}$ in a period of three hours.

The kinetics of these exchanges are not significantly modified by variations in the lumen concentrations of $\mathrm{Na}^{+}$. The excretion of $\mathrm{K}^{+}$seems to arise from a specific active mechanism : persisting in the presence of a concentration gradient, and not'affected by the level of sodium.

The results are comparable before and after infusions of aldosterone for three hours (30 $\mu \mathrm{g}$ $\mathrm{kg}^{-1} \mathrm{~m}^{-1}$ ) or intramuscular injection of an aldosterone inhibitor (8 $\mathrm{Iog} \mathrm{CB}, 15 \mathrm{mg} \mathrm{kg}^{-1} \mathrm{j}^{-1}$ for three days prior to the experiment).

The same technique applied to the dog confirmed the results obtained in this species and those observed in man (an increased reabsorption of sodium and water in the presence of aldosterone, a smaller excretion of potassium).

There are differences between monogastric animals and small ruminants as regards the nature and mechanism. 